\title{
Application of POAC on Community-Based Urban Groundwater Management
}

\author{
Sahda Derana \\ Soegijapranata Catholic University \\ sahda.derana@gmail.com
}

\begin{abstract}
Community-based water management is intended to manage natural assets and to meet the water needs of households in the community. The management by the community takes form of informal management that focuses on social interaction, social norms, and relationships between people in the community. Although it is informal, this form of organization needs to pay attention on aspects of formal management covering planning, organizing, actuating, and controlling (POAC). To find out how the application of POAC in community-based water management, the research conducted case study of two locations in Kedungmundu village, Semarang City, Central Java, Indonesia. This research found that the implementation of management in the community-based urban groundwater in both locations faced various kinds of problems: lack of understanding of the community on how to manage their assets properly, no clear purpose of their management, absence of independence oversight, and lack of good communication. The results can be the evaluations for the management in both locations and for developing knowledge and practical insight of POAC application on similar communitybased urban groundwater management in different locations for them to become sustainable management.
\end{abstract}

Keywords: informal management, community based management, groundwater management

\section{INTRODUCTION}

Today the use of ground water as a source of clean water for the community is increasing. One cause is a decrease in surface water quality. Since 2014, the quality of raw water in Indonesia has declined, around $65 \%$ of the rivers in Indonesia have experienced pollution and the water is thus unconsumable. Pollution is not only on surface water, groundwater quality in big cities has also decreased and is not suitable for consumption (WEPA, 2018; Kementrian PPN/ Bappenas, 2019). Nevertheless ground water is still considered suitable as raw water.

Inadequate availability and high demand of raw water by community are not accompanied by the coverage of existing piped water services. According to the Ministry 
of PPN/Bappenas (2019), up to 2018 the piped water services in Indonesia covered only $20.29 \%$ and 59.6\% of the services comes from the Municipal Waterworks (in Indonesian: PDAM, Perusahaan Daerah Air Minum). The limited availability of clean water is exacerbated by the declining quality of surface water and the piped water infrastructure provided by the government has not yet reached all communities. These have forced people to look for alternatives themselves from ground water.

The Government of Indonesia through Government Regulation no 121/2015 about Managing Water Resources (in Indonesian: PP No 121 Tahun 2015 tentang Pengusahaan Sumber Daya Air) article 2 paragraph 2 and 3 states the exploitation of water resources is intended to increase utilization of water resources for the welfare of the community. Furthermore, the exploitation of water resources as referred to in paragraph 2 is carried out based on the principle of joint and family business ${ }^{1}$. Referring to the regulation, the community has the right to manage and utilize their groundwater assets in groups and in a shared interest.

Management of natural resources by the community (Community Based Management or $\mathrm{CBM}$ ) is natural asset management activities by a community that promote sustainability. Although this is considered good and will benefit the community, its implementation requires caution. Urban communities are developing dynamically and water supply systems need the support of institutions or organizations in management, planning and engineering (Sally et al., 2014).

The area of the city of Semarang covers $373.70 \mathrm{~km}^{2}$ with a population density of $1,668,578$ people, but the coverage of piped water by PDAMs reached only $40.58 \%$ in

\footnotetext{
${ }^{1}$ PP was dropped, Constitutional Court of Indonesia had canceled Law Number 7 of 2004 concerning Water Resources (SDA).
} 
2018 (BPPSPAM, 2020). Communities that do not have access to clean water provided by PDAM choose to use other water sources such as ground water as an alternative. A group of residents in Kedungmundu village, Tembalang Sub-Distric, Semarang City, Indonesia do this. There are two areas that use ground water as their clean water source. They are Sinar Waluyo Housing and Karanggawang Lama.

A well located in Sinar Waluyo Housing has been more than thirty years old and is a relic well built by the housing developer. The well is managed by the community representatives under the name of Paguyuban Pelanggan Air Sumur 02 Sinar Waluyo Housing. The first well in the second location (Karanggawang Lama) was built in 2011 by the help of the program of PNPM Mandiri Perkotaan, Semarang and the second well was built in 2018 using a term loan from Koperasi KSP Dana Amanah Pemberdayaan Masyarakat TUNAS JAYA which was originally a BKM (Community Self-Reliance Agency) of Kedungmundu village. BKM is an organization formed by the 1999 Urban Poverty Reduction Program (P2KP) and adopted by the PNPM Urban rogram. Both wells are managed by representatives of the residents under the name of Team Water Management Kedung Tirta, Karanggawang Lama.

The initial survey on implementation of the water management in both locations found various problems. They do not have organizational structure, the division of performance is not in accordance with their capacity, lack of good internal communication exists, and there is no internal policy. The purpose of this study is to determine informal management process in urban groundwater management in the two areas in Kedungmundu village, Semarang. In particularly, the research aims to know application of POAC in community-based urban groundwater management in the Air Well 02 Customer Housing Association Sinar Waluyo Housing and the Kedung Tirta Water Management Team, Karanggawang Lama. 


\section{LITERATURE REVIEW}

\section{Community Based Management (CBM)}

Community-based management $(\mathrm{CBM})$ is the management of natural resources that involves the community in its management. The management model through CBM focuses on empowerment and sustainability by increasing ownership (Kativhu et al., 2018). CBM is a way to overcome poverty and natural resources by involving traditional leaders, government, nongovernmental organizations in making decisions (Wilmsen et al., 2008; USAID, 2009). The highest decision in the management of natural resources is the community itself, so that they can get maximum benefits. Through CBM, the welfare of the community, form democratic governance and gender equality can expectantly be improved (USAID, 2009). In addition, the existence of $\mathrm{CBM}$ enables the community to manage and control the natural resources they have on an ongoing basis (Mbaiwa, 2015).

In the implementation of CBM, it is necessary to pay attention to six aspects: equity, empowerment, conflict resolution, knowledge and awareness, biodiversity protection, and sustainable utilization. Equity refers to distribution and social and economic benefits to each group. Empowerment means to involve and give power to the community to manage their natural assets. Conflict resolution implies responsive and adaptive in dealing with intraconflicts, inter-conflicts, and supra-conflicts. While knowledge and awareness means the exchange of information, technology, social and traditional culture with modern. Biodiversity protection relates to increasing public awareness of nature conservation. Finally, sustainable utilization means using and encouraging people to use natural resources sustainably (Kellert $e t$ al., 2000; Ochola et al., 2010). 


\section{Informal Organization Management}

Community-based management is included in the management of informal organizations which carry social values that apply within the community group. Informal management consists of a group of people formed on the basis of interactions, norms, and social values (Sudaryono, 2017; Irawan, 2018). Although it is an informal organization, it certainly needs to pay attention to the function of management for the sustainability of the organization itself (Badrudin, 2015; Wijaya \& Rifa'i, 2016) :

a. Planning: Determine and construct vision, mission, strategy, and make decisions in the organization in order to achieve the desired goals and results.

b. Organizing: Determine and classify human resources according to their abilities, tasks, responsibilities, and supporting facilities so that the organization can run effectively and efficiently in achieving its goals.

c. Actuating: Directing, coordinating, and motivating members so that the program that has been designed shows progress and raises concern from outside parties (local government/non-government organizations).

d. Controlling: Observation and evaluation of the programs carried out in order to remain in accordance with agreed objectives through direct control, indirect control, and exception control.

\section{RESEARCH METHOD}

This research used a qualitative ethnographic method by conducting interviews and observations. The ethnographic method was chosen because this study wanted to delve deeper into the meaning and events of the behavior, language and actions of community groups involved in groundwater management in their area. Interviews were conducted to 
administrators of the Paguyuban Pelanggan Air Sumur 02 Sinar Waluyo Housing, administrators Team Water Management Kedung Tirta, Karanggawang Lama, and administrators of the BKM of Kedungmundu village. Aspects and sources of data used are as presented in table 1 .

Observations were to spot performance and behavior of the managers in implementation of POAC, internal communication, and control and supervision of the performance of their organizations.

Table 1. Data source

\begin{tabular}{|c|c|c|c|c|}
\hline Aspect & Dimension & Indicator & Method & Source \\
\hline \multirow{7}{*}{ Planning } & \multirow{3}{*}{$\begin{array}{l}\text { Vision \& } \\
\text { mission }\end{array}$} & \multirow{2}{*}{ Formation } & Interview & Manager \\
\hline & & & Document & Manager \\
\hline & & Experience value & Interview & Manager \\
\hline & \multirow{2}{*}{ Strategy } & Short-term strategy & Interview & Manager \\
\hline & & Long-term strategy & Interview & Manager \\
\hline & \multirow{2}{*}{$\begin{array}{l}\text { Decision } \\
\text { maker }\end{array}$} & Determination of policy & Interview & Manager \\
\hline & & Decision holder & Interview & Manager \\
\hline \multirow{5}{*}{ Organizing } & \multirow{3}{*}{ Staffing } & \multirow{2}{*}{ Organizational structure } & Interview & Manager \\
\hline & & & Document & Manager \\
\hline & & $\begin{array}{l}\text { Member/manager } \\
\text { competencies }\end{array}$ & Interview & Manager \\
\hline & \multirow{2}{*}{ Facilitating } & Incentive/salary/wages & Interview & Manager \\
\hline & & Supporting technology & Interview & Manager \\
\hline Actuating & Briefing & Job desc determination & Interview & Manager \\
\hline
\end{tabular}




\begin{tabular}{|c|c|c|c|c|}
\hline & & Process monitoring & Interview & Manager \\
\hline & & Communication & Interview & Manager \\
\hline & & Job desc distribution & Interview & Manager \\
\hline & Motivation & $\begin{array}{l}\text { Carrying capacity } \\
\text { among members }\end{array}$ & Interview & Manager \\
\hline & $\begin{array}{l}\text { Direct } \\
\text { control }\end{array}$ & $\begin{array}{l}\text { Supervision and } \\
\text { direction from the } \\
\text { chairman to the } \\
\text { members }\end{array}$ & Interview & Manager \\
\hline Controlling & $\begin{array}{l}\text { Indirect } \\
\text { control }\end{array}$ & $\begin{array}{l}\text { Reporting conditions } \\
\text { from members or } \\
\text { consumers to the chief } \\
\text { manager }\end{array}$ & 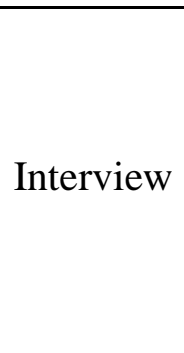 & Manager \\
\hline & $\begin{array}{l}\text { Control of } \\
\text { exceptions }\end{array}$ & $\begin{array}{l}\text { Conditional policy and } \\
\text { handling }\end{array}$ & Interview & Manager \\
\hline
\end{tabular}

This research compared community-based water management based on management aspects of Planning, Organizing, Actuating, and Controlling (POAC) in both locations, Sinar Waluyo Housing and Karanggawang Lama. The purpose was to determine the informal management process in both urban groundwater management, in particularly the application of POAC in community-based urban groundwater management in the Air Well 02 Customer Housing Association Sinar Waluyo Housing and the Kedung Tirta Water Management Team, Karanggawang Lama. 
Data collection through interviews and observations was carried out throughout August 2019 to March 2020. Based on the interviews and observations, the analysis was directed to understand development and obstacles that are faced by the water managers in running their organizations and activities in terms of informal management.

\section{RESULTS AND DISCUSSION}

These two locations have differences in terms of social and economic status and the background of the establishment of groundwater well. The first location, Sinar Waluyo is a housing complex that is generally inhabited by middle and upper social and economic groups. The well at this location is a relic of the housing developer around thirty years ago (1980s) and had been transferred to the community when the developer left the site. The management of the well is currently held by the community under the name of the Association of Paguyuban Pelanggan Air Sumur 02 Sinar Waluyo Housing. At present, the water officials build a residential and stall at the location of the well. Switching the function of the well building was done without approval of the stakeholders who are responsible for the neighborhood at the location (chairman RT and RW).

The second location, Karanggawang Lama is a township in urban areas that are mostly inhabited by low social and economic groups. This location has two wells originating from two different sources. The first well was built in 2011 and was a relief well from a Government program, PNPM Mandiri Perkotaan. Whereas the second well is a well built with a term loan in 2018. The well is managed by the community under the name of the Tim Pengelola Air Kedung Tirta, Karanggawang Lama. Water management at this location is held by community representatives who apparently also serve as administrators of BKM Kedungmundu village. 
From the interview and observation, it reveals that the management in both locations implemented unhealthy management in their POAC.

Planning

The initial stage in forming an organization is the need to determine vision, mission, strategy, and decision making, which become initial planning of the organization for objectives of the organization can be achieved well in the future. Absence of planning indicates the organization has no goals, no guidelines for implementation that possibly result in waste, no control and decision making that are the key for the future of the organization (Badrudin, 2015; Wijaya \& Rifa'i, 2016).

The managers in two locations did not do planning. They did not have vision and mission, and thus the purpose of the organization is not clear. They just did the routines. Internal or external conflicts related to consumers resolute spontaneously. The resolution of internal conflicts was only temporary so that they potentially resulted in unpredictable long-term conflicts. About this will be discussed further in the organizing aspect.

\section{Organizing}

Organizing is a stage in which things are grouped in accordance with predetermined and mutually agreed criteria. Wijaya (2016) stated that organizing is the stage of determining activities of natural resource management effectively and efficiently in order to facilitate implementing staffing and providing facilities. In addition, the manager can also determine what divisions needed in running the organization. Through this stage, the manager can find out human resource that is specifically needed for management position.

The managers in both locations did not have specific standards and criteria of the candidates for the management position of the organization. The management was elected internally and by direct appointment. There was difference between the two locations in terms 
of management selection. In the first location, management members are chosen by the chairman through considerations with the old management. Such selection had no basis whatsoever, so the elected members voluntarily or forcefully joined the water management. Whereas in the second location, members are chosen internally by the initial manager who is also the member of the BKM Kedungmundu village. The elected members of the management are those who had conflicts when the aid was provided in establishing the well. The initial management thought that this way could ease the conflict occurred between the community and the initial water management.

Furthermore, the management in both locations did not provide supporting facilities and salaries, thereby this worsened the condition of their internal management. Some elected management members did not carry out their responsibilities properly and this left extra job for the other members. Some members chose not to do their responsibilities due to their work and economic responsibilities to their families. The others chose to keep doing the management work because of their social and religious values even though they did not get any facilities. They believed that they will get better reward from God than that is given by humans for every good action they did to others.

\section{Actuating}

This stage is the stage of carrying out the planned activities. However, because the planning and organizing stages were not carried out by the managers in the two locations, the extent of the development of water management cannot be detected. Management was carried out spontaneously and routinely. The direction was carried out by the chairman or the person in charge or by the water officer only if the well is damage and the connection pipe to consumer has problem. Coordination between the management members at the first location was done through a personal chat app or during a worship gathering in a place and was conducted 
conditionally in the event of a conflict. In addition to internal coordination, the manager also coordinated with the water coordinator in each RT for monthly payment of water bill. The manager in the second location also used a personal chat app for coordination and it was conducted conditionally in the event of a conflict. The managers in both locations carried out the business and all activities spontaneously. This way makes assessment on development of the water management in the two locations cannot be predicted.

\section{Controlling}

Controlling is an activity to collectively monitor and make decisions on all activities carried out in management so as not to conflict with the SOP (standard operating procedure) that has been determined and mutually agreed upon (Badrudin, 2015; Wijaya \& Rifa'i, 2016).

In the case of the first location, lack of communication between the chairman and the water officer made monitoring process is difficult to be carried out. This lack of communication eventually led the local stakeholders (chairman RT and RW) to take part in monitoring and reprimanding managers about water management related activities. Whereas in the second location, the manager was the initial water manager and also was the board of BKM of Kedungmundu village. Supervision on water management activities that should be carried out independently and monitored in accordance with SOPs in PNPM Mandiri Perkotaan were in fact not done. The absence of independence and the existence of multi positions allowed for the potential interests of the group, such as ease of getting access to assistance without going through the proper procedures. 


\section{CONCLUSION AND RECOMMENDATIONS}

\section{Conclusion}

Organizational management is formed and designed to facilitate the organizations to achieve their goals systematically and efficiently and to sustain management. To realize this, an organization needs to pay attention to four aspects of management covering planning, organizing, actuating, and controlling (Badrudin, 2015).

What happens in both community-based groundwater managements was that they did not carry out all the stages of the management aspect. The management members were formed on the basis of social and religious values so that the persuasive approach was preferred in carrying out all water management activities. From the social point of view, it had proven to be effective, but in the long run it possibly brought up new problems in their internal management, they were loss of some members of the management due to their economic needs since they did not get any facilities and salaries for their hard work in the water management.

Absence of standard organizational structure, establishment of divisions, and criteria to become a member of the management made the water management in both locations worked without clear objectives. The selection of members that was conducted internally and utilized existing situations resulted in long-term conflicts that cannot be predicted by the managers. The current main conflict is that some members of the management in the two location were inactive because there were no supporting facilities, salaries, and it was a compulsory to participate in managing water. The inactive members had given extra job to the remaining management and impacted the performance of the water managers and the development of the organization in the two locations.

Lack of communication was a major factor for supervision failure in the first location and ultimately urged the stakeholders on the social environment in the location to be indirect 
supervisor and policy maker. Whereas in the second location, the absence of independent supervision and concurrent positions as water managers and management of BKM caused the supervision and development of the management could not be monitored and assessed objectively. If this continues it can bring up the interests of the group between the water manager and the BKM itself in the future.

\section{Recommendations}

From the findings, the managers in the two locations need to re-evaluate all groundwater management activities in their environment. Through planning, the managers can find out what stages they need to do in the short and long terms. Involvement of outside parties, both the regional government and non-government organizations (Non-Governmental Organizations) who are experts in their fields, is needed to assist and supervise the management of the two locations

Although this management is community based, there is still a need for planning all activities within their organization to make it sustainable management. Although CBM is seen as far more beneficial for the community in managing their natural assets, it still requires special attention in its implementation in the long run. Even though it is classified as informal management, CBM in any place and sector must still pay attention on and need to implement POAC for being sustainable management.

\section{REFERENCES}

Badrudin 2015. DASAR - DASAR MANAJEMEN. Bandung: Alfabeta. Tersedia di http://digilib.uinsgd.ac.id/4002/1/DASAR - DASAR MANAJEMEN.pdf.

BPPSPAM 2020. Buku Kinerja BUMD Penyelenggawa SPAM 2019. Jakarta: Kementerian Pekerjaan Umum Dan Perumahan Rakyat. Tersedia di 
http://sim.ciptakarya.pu.go.id/bppspam/detail_profile/55.

Irawan, B. 2018. Organisasi Formal Dan Informal: Tinjauan Konsep, Perbandingan, dan Studi Kasus. Jurnal Administrative Reform, 6(4): 197-208. Tersedia di http://ejournals.unmul.ac.id/index.php/JAR/article/viewFile/1921/1458.

Kativhu, T., Mazvimavi, D., Tevera, D. \& Nhapi, I. 2018. Implementation of Community Based Management (CBM) in Zimbabwe: The dichotomy of theory and practice and its influence on sustainability of rural water supply systems. Physics and Chemistry of the Earth, 106: 73-82. Tersedia di https://doi.org/10.1016/j.pce.2018.05.003.

Kellert, S.R., Mehta, J.N., Ebbin, S.A. \& Lichtenfeld, L.L. 2000. Community natural resource management: Promise, rhetoric, and reality. Society and Natural Resources, 13(8): 705-715. Tersedia di https://www.mendeley.com/catalogue/community-naturalresource-management-promise-rhetoric-reality/.

Kementrian PPN/ Bappenas 2019. Rencana Pembangunan Jangka Menengah Nasional 20202024. Tersedia di https://www.bappenas.go.id/files/rpjmn/Narasi RPJMN IV 20202024_Revisi 28 Juni 2019.pdf.

Mbaiwa, J.E. 2015. Community-Based Natural Resource Management in Botswana. Tersedia di https://www.researchgate.net/publication/285488112_CommunityBased_Natural_Resource_Management_in_Botswana.

Ochola, W.O., Sanginga, P.C. \& Bekalo, I. 2010. Managing Natural Resources for Development in Africa: A Resource Book. Nairobi: University of Nairobi Press (UONP). Tersedia di https://books.google.co.id/books?hl=id\&lr=\&id=WDLpYXhE9_UC\&oi=fnd\&pg=P A165\&dq=Community+Based+Natural+Resources+Management+\&ots=a_aTFy9zT M\&sig=adDjkisauYpxtmsjxkvDroBGsBw\&redir_esc=y\#v=onepage\&q=Community 
Based Natural Resources Management $\& \mathrm{f}=$ false.

PP No 121 Tahun 2015 tentang Pengusahaan Sumber Daya Air. Tersedia di https://kppip.go.id/download/peraturan/pp/PP-No-121-TAHUN-2015-PENG-

SDA.pdf.

Sally, Z., Gaskin, S.J., Folifac, F. \& Kometa, S.S. 2014. The effect of urbanization on community-managed water supply: Case study of Buea, Cameroon. Community Development Journal, $\quad 49(4): \quad 524-540 . \quad$ Tersedia di https://www.researchgate.net/publication/275380411_The_effect_of_urbanization_o n_community-managed_water_supply_Case_study_of_Buea_Cameroon.

Sudaryono 2017. Pengantar Manajemen: Teori dan Kasus. Yogyakarta: CAPS (Center for Academic Publishing Service).

USAID 2009. Environmental Guidelines for Small-Scale Activities in Africa (EGSSAA): Community-Based Natural Resource Management Community-Based Natural Resource Management ( CBNRM ). (11): 1-53. Tersedia di www.encapafrica.org.

WEPA 2018. Water Environmental Partnership in Asia (WEPA). Tokyo. Tersedia di http://www.wepa-db.net/.

Wijaya, C. \& Rifa'i, M. 2016. DASAR-DASAR MANAJEMEN. Medan: Perdana Publishing. Tersedia di https://docplayer.info/64145967-Dasar-dasar-manajemen.html.

Wilmsen, C., Elmendorf, W.F., Fisher, L., Ross, J., Sarathy, B. \& Wells, G. 2008. Partnerships for empowerment: Participatory research for community-based natural resource management. Partnerships for Empowerment: Participatory Research for Community-Based Natural Resource Management. London: Earthscan. Tersedia di https://www.taylorfrancis.com/books/e/9781849772143. 